\title{
ANALYSIS OF MATHEMATICAL PROBLEM-SOLVING SKILLS AND STUDENT PROCESS SKILLS IN PROBLEM-BASED LEARNING
}

\author{
Ahmat Wakit $^{1 \varpi}$ dan R. Hadapiningradja Kusumodestoni ${ }^{2}$
}

Universitas Islam Nahdlatul Ulama Jepara

\section{Info Artikel \\ Sejarah Artikel: \\ Diterima 26Agt 2018 \\ Direvisi 5 Sept 2018 \\ Disetujui 29 Okt 2018 \\ Keywords: Mathematical problem solving skills, student process skills, problem-based learning}

Paper type:

Research paper

\section{Abstract}

This study aims to (1) determine the characteristics of mathematics learning with problem-based learning in the 2013 curriculum, and 2) describe mathematical problem-solving abilities and student process skills in learning with the problem-based learning model. This type of research is a mixed method research with the concurrent embedded design which is a combination of qualitative and quantitative research methods that are carried out together. In this study, qualitative research is the primary method while quantitative research is a secondary method. The research subjects were 37 students of MTS PB Roudlotul Mubtadiin Balekambang Jepara. Student process skills observed include observing, questioning, gathering information, associating, and forming networks I communicating. The results of this study indicate (1) the learning device with the problem-based learning model in the 2013 curriculum is effective because it meets the completeness test in the experimental class and the comparative test that the experimental class mathematical problemsolving ability is better than the control class mathematical problem-solving ability, (2) score students ' problem-solving ability in the experimental class increased after following the learning with the problem-based learning model and the students' process skills in following the learning in the 2013 curriculum increased significantly.

\begin{abstract}
Abstrak
Penelitian ini bertujuan untuk (1) mengetahui karakteristik pembelajaran matematika dengan problem based learning pada kurikulum 2013, dan 2) mendeskripsikan kemampuan pemecahan masalah matematika dan keterampilan proses siswa pada pembelajaran dengan model problem based learning. Jenis penelitian ini adalah penelitian mixed method dengan concurrent embedded design yaitu penggabungan metode penelitian kualitatif dan kuantitatif yang dilakukan secara bersama-sama. Dalam penelitian ini, penelitian kualitatif sebagai metode primer sedangkan penelitian kuantitatif sebagai metode sekunder. Subjek penelitiannya adalah siswa kelas VII MTs PB Roudlotul Mubtadiin Balekambang Jepara sebanyak 37 siswa. Keterampilan proses siswa yang diamati meliputi mengamati, menanya, mengumpulkan informasi, mengasosiasikan, dan membentuk jejaring/ mengkomunikasikan. Hasil Penelitian ini menunjukkan (1) perangkat pembelajaran dengan model problem based learning pada kurikulum 2013 efektif karena memenuhi uji ketuntasan pada kelas eksperimen dan uji banding yaitu kemampuan pemecahan masalah matematika kelas eksperimen lebih baik dari pada kemampuan pemecahan masalah matematika kelas kontrol, (2) rata-rata kemampuan pemecahan masalah siswa kelas eksperimen meningkat setelah mengikuti pembelajaran dengan model problem based learning dan keterampilan proses siswa dalam mengikuti pembelajaran pada kurikulum 2013 mengalami peningkatan secara signifikan.
\end{abstract}

Alamat korespondensi:

Program Studi Pendidikan Matematika, Universitas Muria Kudus

Kampus UMK Gondangmanis, Bae Kudus Gd. L. lantai 1 Ruang 2 PO. BOX 53 Kudus

Tlp (0291) 438229 Fax. (0291) 437198

E-mail: ahmatwakit@unisnu.ac.id 
Ahmat Wakit dan R. Hadapiningradja Kusumodestoni

Anargya: Jurnal Pendidikan Matematika, Vol. 1 No.2, Oktober 2018

\section{PENDAHULUAN}

Tinggi rendahnya mutu pendidikan tidak dapat terlepas dari kualitas pembelajaran yang didesain dan dikelola oleh guru. Guru memegang peranan penting dalam membangun karakter siswa sehingga guru perlu mengembangkan metode pembelajaran bermuatan karakter diberbagai bidang, salah satunya adalah pembelajaran matematika. Salah satu tujuan dari pembelajaran matematika adalah agar siswa memiliki memecahkan masalah.

Menurut Häkkinen $(2017 ; 21)$ pendidikan harus lebih fokus pada bidang keterampilan tertentu seperti keterampilan pemecahan masalah, keterampilan berkolaborasi dan lainlain. Kemampuan pemecahan masalah sangat diperlukan dalam kehidupan sehari-hari guna mengatasi permasalahan yang ada. Oleh karena itu diperlukan pengajaran yang dapat memacu kemampuan siswa dalam memecahkan masalah matematika.

Hasil dari tes awal menunjukkan bahwa kemampuan pemecahan masalah siswa MTs PB Roudlotul Mubtadiin Balekambang tingkat masih rendah. Rendahnya kemampuan pemecahan masalah ditunjukkan dari hasil tes kemampuan pemecahan masalah yang dilakukan peneliti pada penelitian awal dengan rata-rata nilai kemampuan pemecahan masalah siswa kelas VII pada materi segitiga dan segiempat adalah 58,67 kurang dari KKM yaitu 70. Rendahnya kemampuan pemecahan masalah siswa disebabkan adanya beberapa kesalahan, seperti tidak dapat memahami masalah dan tidak dapat merancang permasalahan.

Empat tahap yang harus dikerjakan dalam pemecahan suatu masalah, yaitu; memahami masalah (Understanding the Problem), merencanakan penyelesaian (Devising A Plan), menyelesaikan masalah sesuai rencana (Carrying Out The Plan) dan memeriksa kembali (Looking Back) (Polya, 1973;5). Hasil penyelesaian siswa pada penelitian awal menunjukkan bahwa 1) siswa tidak dapat memahami permasalahan sehingga siswa tidak dapat merencanakan dan menyelesaikan permasalahan dengan benar; 2) siswa mengalami kesulitan dalam merencanakan penyelesaian masalah sehingga siswa tidak mampu menyelesaikan permasalahan dengan benar; 3) Kesalahan siswa disebabkan karena siswa tidak mampu menerapkan empat tahap penyelesaian masalah. Tahap pertama memahami masalah, siswa kurang cermat dalam memahami soal sehingga tidak faham apa yang diketahui dan apa yang ditanyakan. Tahap kedua merencanakan penyelesaian, siswa tidak dapat mengumpulkan informasi dan menerapkan konsep matematika. Tahap ketiga menyelesaikan masalah, siswa tidak dapat menyelesaikan masalah karena tidak mengerti apa yang dilakukan. Tahap keempat memeriksa kembali, siswa tidak mengoreksi jawaban yang sudah dikerjakan sehingga tidak mengetahui bahwa jawaban benar atau salah. Bradshaw, Z. \& Hazell, A. (2017;37) menambahkan menjelaskan bahwa umumnya dalam menyelesaikan masalah siswa cenderung hanya terfokus pada hasil yang ingin dicapai dan mengabaikan langkah proses yang sesuai.

Model pembelajaran yang sesuai juga berpengaruh terhadap pemahaman dan kemampuan siswa dalam menyelesaikan permasalahan yang ada. Guru dapat memotivasi siswa agar lebih tertarik mempelajari matematika dengan mengaitkan materi yang dipelajari dengan permasalahan dalam kehidupan seharihari. Karatas, I. \& Baki, A $(2013 ; 255)$ menjelaskan bahwa pembelajaran berbasis masalah dapat meningkatkan pemahaman dan kemampuan pemecahan masalah siswa secara signifikan. Pembelajaran berbasis masalah atau problem based learning (PBL) sangat sesuai dalam mengatasi permasalahan yang ada. Savery (2006;15) menambahkan bahwa PBL adalah pendekatan pembelajaran yang berpusat pada siswa yang memberdayakan peserta siswa untuk melakukan penelitian, mengintegrasikan teori dan praktik, dan menerapkan pengetahuan dan keterampilan untuk mengembangkan solusi yang layak untuk masalah yang ditetapkan.Kegiatan pokok pada model ini adalah memecahkan permasalahan melalui rangkaian kegiatan kelompok berdasarkan permasalahan sehari-hari sehingga siswa dapat terlibat aktif dalam pembelajaran.

Menurut Davidson, N., \& Major, C. H. (2014;28) problem based learning mempunyai dampak positif pada aktifitas dan kerjasama siswa. Fokus utama model pembelajaran ini adalah aktivitas siswa, aktivitas pembelajaran akan lebih maksimal dengan pendekatan yang sesuai yaitu pendekatan saintifik. Langkahlangkah pada pendekatan saintifik yaitu mengamati, menanya, mengumpulkan informasi, mengasosiasikan, dan membentuk jejaring/mengkomunikasikan. Servant \& Miklos (2018;8) menambahkan bahwa jika guru ingin menggunakan PBL, maka harus memberikan perhatian khusus pada fase diskusi dan penggunaan beragam permasalahan. Pernyataan ini sesuai dengan hasil penelitian dari Ari \& Katranci (2014;1830) yang menyatakan bahwa PBL dapat digunakan karena meningkatkan kemampuan berpikir siswa dan dapat membantu 
siswa dalam meningkatkan keterampilan pemecahan masalah, tetapi persiapan dan praktik metode ini memakan waktu.

Keberhasilan pembelajaran juga dibarengi dengan ketersediaan perangkat pembelajaran yang berkualitas. Menurut Kamaruddin $(2012 ; 228)$ pendidikan karakter harus dilakukan dengan komitmen tinggi dan perbaikan terusmenerus dari perilaku yang dilakukan. Belum tersedianya perangkat pembelajaran model problem based learning dengan pendekatan saintifik bermuatan karakter, juga merupakan faktor yang membuat siswa tidak dapat memaparkan pengetahuannya untuk mencari penyelesaian dari masalah yang dihadapi. Oleh karena itu perlu adanya pembelajaran matematika yang menitikberatkan pada keterampilan proses siswa atau aktivitas siswa dalam mengikuti pembelajaran dan meningkatkan kemampuan pemecahan masalah matematik.

Tujuan dari penelitian ini adalah untuk (1) mengetahui karakteristik pembelajaran matematika dengan problem based learning pada kurikulum 2013, dan 2) mendeskripsikan kemampuan pemecahan masalah matematika dan keterampilan proses siswa pada pembelajaran dengan model problem based learning.

\section{METODE PENELITIAN}

Metode penelitian yang digunakan adalah metode kombinasi (mixed methods). Sugiyono (2015:404) menjelaskan bahwa metode penelitian kombinasi adalah metode penelitian yang menggabungkan metode kualitatif dan kuantitatif. Model kombinasi yang digunakan adalah concurrent embedded yang memfokuskan penelitian pada penggabungan metode penelitian kualitatif dan kuantitatif secara bersama-sama.

Penelitian ini dilaksanakan di MTs PB Roudlotul Mubtadiin Balekambang Jepara. Populasi dalam penelitian ini adalah seluruh siswa kelas VII. Sampel penelitian adalah kelas F sebagai kelas eksperimen dan kelas $G$ sebagai kelas kontrol.

Teknik pengumpulan data dalam penelitian ini menggunakan angket, wawancara, pengamatan dan tes. Observasi digunakan untuk mengetahui keterampilan proses siswa selama pembelajaran berlangsung. Angket digunakan untuk mengetahui keterpakaian penggunaan perangkat pembelajaran dengan model problem based learning pada kurikulum 2013. Wawancara digunakan untuk mengetahui karakteristik kemampuan pemecahan masalah matematika secara mendalam. Tes Kemampuan Pemecahan Masalah (TKPM) menggunakan lembar soal
TKPM digunakan untuk mengukur kemampuan pemecahan masalah matematika.

Analisis data kuantitatif dilakukan untuk menguji keefektifan pembelajaran yang diperoleh dari ketuntasan kemampuan pemecahan masalah matematika kelas eksperimen, dan uji banding rataan kemampuan pemecahan masalah matematika kelas eksperimen dan kontrol. Analisis data kualitatif dilakukan dengan memilih 6 siswa dari kelas ekperimen yaitu 2 siswa mewakili kelompok siswa dengan kemampuan rendah, 2 siswa mewakili kelompok siswa dengan kemampuan sedang dan 2 siswa mewakili kelompok siswa dengan kemampuan tinggi, kemudian dilakukan observasi secara mendalam selama pembelajran dan wawancara setelah post test selesai.

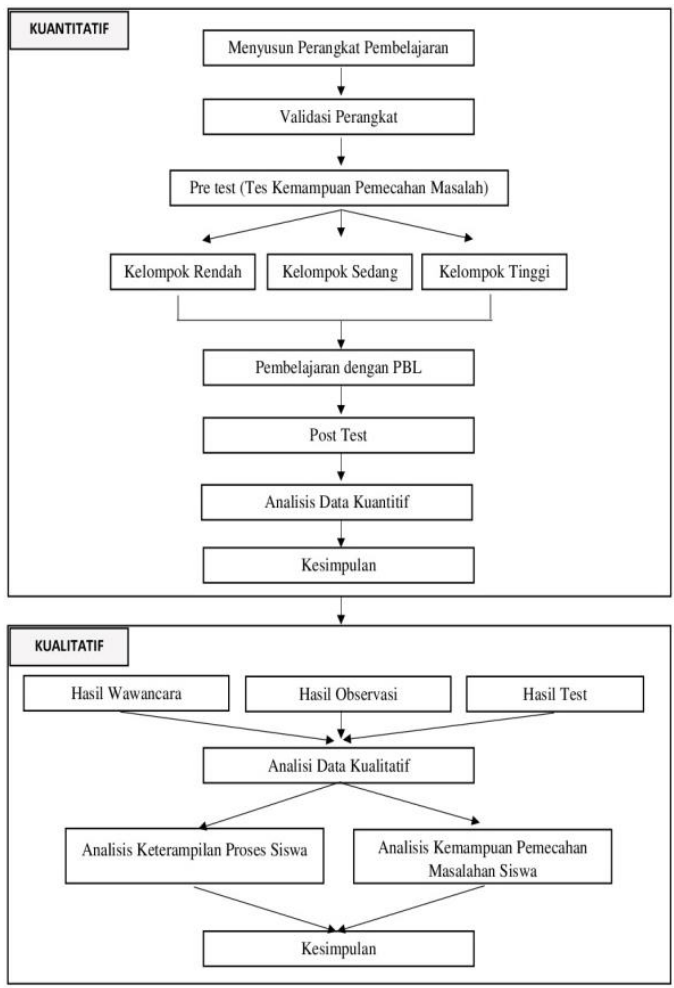

Gambar 1. Alur Penelitian

\section{HASIL DAN PEMBAHASAN}

Hasil penelitian ini menunjukkan bahwa (1) perangkat pembelajaran dengan model problem based learning pada kurikulum 2013 efektif karena memenuhi uji ketuntasan pada kelas eksperimen dan uji banding yaitu kemampuan pemecahan masalah matematika kelas eksperimen lebih baik dari pada kemampuan pemecahan masalah matematika kelas kontrol, (2) kemampuan pemecahan masalah siswa kelas eksperimen cenderung 
meningkat setelah mengikuti pembelajaran dengan model problem based learning dan keterampilan proses siswa dalam mengikuti pembelajaran pada kurikulum 2013 mengalami peningkatan secara signifikan.

Efektivitas perangkat pembelajaran diperoleh dari dua hal yaitu uji ketuntasan dan uji banding. Output SPSS pada tabel One Sample Test menunjukkan $t_{\text {hitung }}=4,149$ dan $t_{\text {table }}$ dengan $\mathrm{dk}=36$ dan taraf signifikan yang digunakan 5\% $=1,688$. Karena $t_{\text {hitung }}=4,149>t_{\text {tabel }}=1,688$, maka $\mathrm{H}_{0}$ ditolak dan $\mathrm{H}_{1}$ diterima. Dapat disimpulkan bahwa rata-rata kemampuan pemecahan masalah siswa yang diajar dengan model problem based learning dengan pendekatan saintifik bermuatan karakter lebih dari 70.

Uji banding maksudnya adalah perbandingan nilai rataan kemampuan pemecahan masalah matematika kelas eksperimen dan kelas kontrol. Output SPSS pada tabel Independent Samples Test diperoleh nilai t hitung $=3,296$. Pada $\alpha=5 \%$ dengan $\mathrm{dk}=37+35$ $2=70$ diperoleh $\mathrm{t}_{\text {tabel }}=1,67$. Jadi, $\mathrm{t}$ hitung $>\mathrm{t}$ tabel Ini berarti $\mathrm{H} 1$ diterima.

Dapat disimpulkan bahwa rata-rata kemampuan pemecahan masalah siswa yang diajar dengan model problem based learning lebih baik dari rata-rata kemampuan pemecahan masalah siswa yang diajar dengan metode ekspositori.

\section{Deskripsi Peningkatan Kemampuan Pemecahan Masalah}

Kemampuan pemecahan masalah siswa meningkat setelah mengikuti pembelajaran dengan model problem based learning dengan kurikulum 2013. Siswa dapat menerapkan setiap langkah pemecahan masalah Polya secara runtut dalam menjawab pertanyaan. Sebelum mengikuti pembelajaran dengan model problem based learning siswa cenderung menjawab pertanyaan secara langsung sehingga sering megalami kesalahan dalam mengidentifikasi masalah atau dalam perhitungannya. Hasil penelitian ini menunjukkan pembelajaran model problem based learning dapat meningkatkan hasil belajar siswa dalam hal ini kemampuan pemecahan masalah. Meningkatnya kemampuan pemecahan masalah siswa dikarenakan siswa dapat melakukan langkah/tahapan pemecahan masalah Polya yaitu memahami masalah, merencanakan penyelesaian, menyelesaikan masalah dan memeriksa kembali. Ke-empat langkah ini mendukung meningkatkan kemampuan pemecahan masalah siswa pada materi segitiga.
Hasil analisis terhadap lembar jawab siswa pada pretest dan posttest menunjukkan bahwa ada perkembangan kemampuan memecahkan masalah siswa. Tahap memahami masalah adalah tahap penting dalam menyelesaikan suatu masalah, bila siswa tidak dapat memahami permasalahan yang ada, siswa tidak dapat menyelesaikan masalah dengan tepat. Pada tahap ini, kemampuan memahami masalah siswa meningkat, hampir seluruh siswa kelas uji coba benar dalam memahami suatu masalah yang diberikan. Tahap merencanakan penyelesaian ini tahap inti dalam menyelesaikan masalah, pada tahap ini memiliki skor paling besar dari pada tahap yang lain. Kemampuan siswa merencanakan penyelesaian meningkat namun peningkatannya masih belum maksimal karena dalam merencanakan penyelesaian siswa dituntut memahami masalah terlebih dahulu dan mengumpulkan informasi/materi yang dapat penunjang dalam menyelesaikan masalah. Tahap menyelesaikan masalah adalah tahap utama dalam menyelesaikan masalah, jika tahap ini tidak dilakukan dengan baik sesuai rencana penyelesaian maka suatu masalah tidak bisa terselesaikan. Dalam hal ini kemampuan siswa menyelesaikan masalah meningkat, meskipun ada siswa yang mendapatkan skor rendah pada tahap ini, disebabkan perencanaan menyelesaikan masalah yang kurang tepat. Tahap akhir dalam menyelesaikan masalah adalah memeriksa kemabali dan menarik kesimpulan. Kemampuan siswa pada tahap ini meningkat, dapat dikatakan rata-rata siswa dapat memeriksa kembali dan menarik kesimpulan dari permasalahan yang ada.

Tahapan dalam menyelesaikan masalah juga diuraikan pada lembar jawab di LKS. LKS yang dikembangkan memuat soal pemecahan masalah dan lembar jawab dengan tahapan pemecahan masalah. Setiap pertemuan siswa mengisi lembar jawab yang disediakan sesuai tahapan Polya, ini menyebabkan siswa terbiasa menyelesaikan permasalah dengan langkah pemecahan masalah polya.

\section{Deskripsi peningkatan keterampilan proses} Pengamatan selama proses berlangsungnya kegiatan pembelajaran dengan untuk mendapatkan informasi-informasi mengenai keterampilan proses dari ke-enam siswa pilihan. Perkembangan keterampilan proses siswa ditunjukkan oleh peningkatan pada ke-lima indikator keterampilan proses siswa. Hasil pengamatan perkembangan masing-masing indikator keterampilan proses dari ke-enam siswa pilihan secara rinci adalah sebagai berikut: 
Ahmat Wakit dan R. Hadapiningradja Kusumodestoni

Anargya: Jurnal Pendidikan Matematika, Vol. 1 No.2, Oktober 2018

\section{Mengamati}

Gambar 2 memperlihatkan adanya peningkatan keterampilan proses ke-enam siswa pada indikator mengamati. Indikator mengamati ini merupakan indikator dari keterampilan proses terhadap pendekatan saintifik. Dengan melihat Gambar 2 dapat dikatakan bahwa rata-rata dari ke-enam siswa pilihan meningkat pada indikator mengamati.

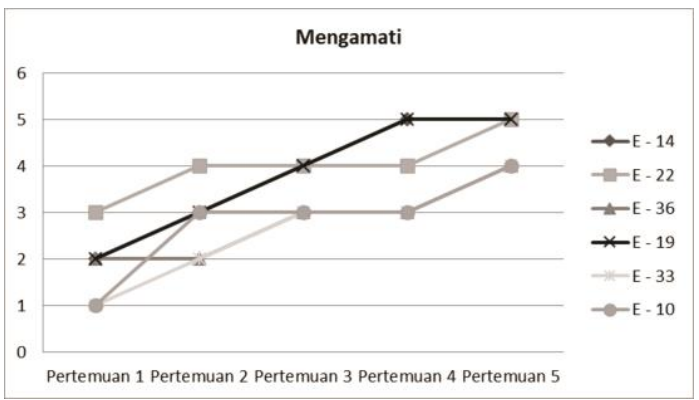

Gambar 2. Grafik Peningkatan Indikator Mengamati

\section{b. Menanya}

Gambar 3 memperlihatkan adanya peningkatan keterampilan proses ke-enam siswa pada indikator menanya. Indikator menanya ini merupakan indikator dari keterampilan proses terhadap pendekatan saintifik. Dengan melihat Gambar 3 dapat dikatakan bahwa rata-rata dari ke-enam siswa pilihan meningkat pada indikator menanya.

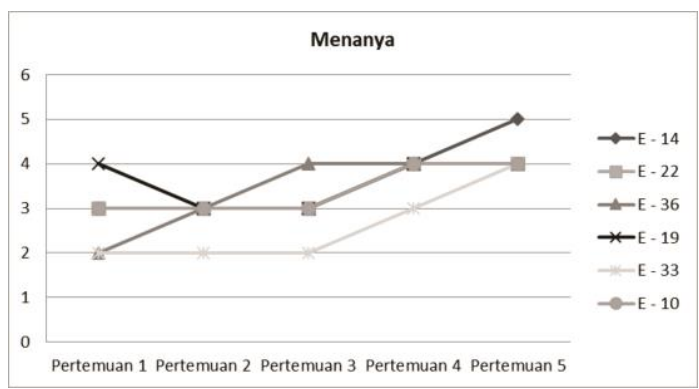

\section{Gambar 3. Grafik Peningkatan Indikator Menanya}

\section{c. Mencoba/Eksperimen}

Gambar 4 memperlihatkan adanya peningkatan keterampilan proses ke-enam siswa pada indikator mencoba/eksperimen. Indikator mencoba ini merupakan indikator dari keterampilan proses terhadap pendekatan saintifik. Dengan melihat Gambar 7 dapat dikatakan bahwa rata-rata dari ke-enam siswa pilihan meningkat pada indikator mencoba.

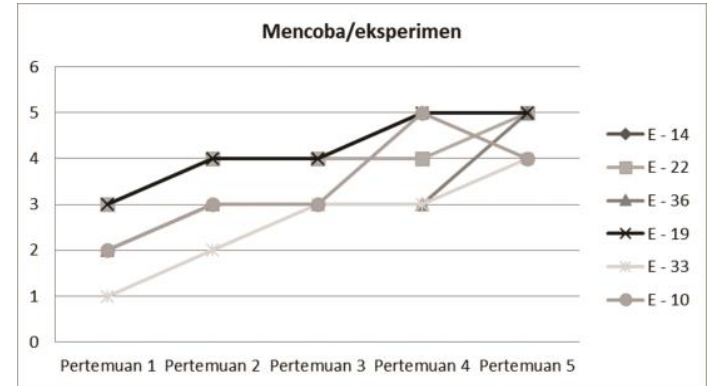

Gambar 4. Grafik Peningkatan Indikator Mencoba/Eksperimen

\section{d. Menalar/asosiasi}

Gambar 5 memperlihatkan adanya peningkatan keterampilan proses ke-enam siswa pada indikator menalar/asosiasi. Indikator menalar ini merupakan indikator dari keterampilan proses terhadap pendekatan saintifik. Dengan melihat Gambar 5 dapat dikatakan bahwa rata-rata dari keenam siswa pilihan meningkat pada indikator menalar.

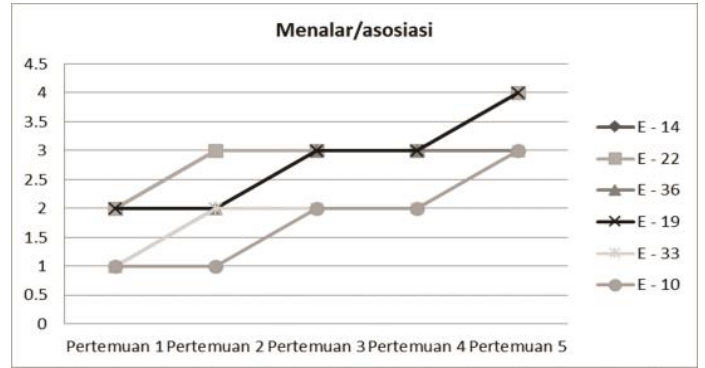

Gambar 5. Grafik Peningkatan Indikator Menalar/Asosiasi

\section{e. Mengkomunikasikan/membentuk jejaring}

Gambar 6 memperlihatkan adanya peningkatan keterampilan proses ke-enam siswa pada indikator mengkomunikasi/ membentuk jejaring. Indikator mengkomunikasikan ini merupakan indikator dari keterampilan proses terhadap pendekatan saintifik. Dengan melihat Gambar 6 dapat dikatakan bahwa rata-rata dari ke-enam siswa pilihan meningkat pada indikator mengkomunikasikan.

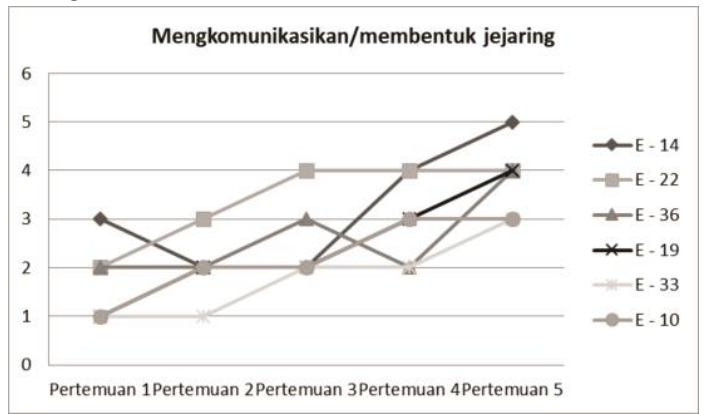

Gambar 6. Grafik Peningkatan Indikator Mengkomunikasikan 
Dari Gambar 2 sampai Gambar 6 memperlihatkan dengan jelas adanya peningkatan keterampilan proses ke-enam siswa pilihan dari setiap pertemuan saat uji coba perangkat yang dikembangkan. Peningkatan keterampilan proses juga ditunjukkan dari ratarata skor tiap pertemuan. Untuk mencapai keterampilan proses yang maksimal, guru harus lebih memfokuskan tahapan mana yang harus dikuatkan/ditekankan khususnya pada siswa yang masih kesulitan dalam mengikuti proses pembelajaran. Menurut 'Ula (2018;58) guru sebaiknya lebih memperhatikan siswa yang masih mengalami kesulitan dalam kemampuan komunikasi matematis. Peningkatan ini terjadi merupakan akibat dari proses pembelajaran dari seseorang. Proses yang dimaksud adalah aktivitas yang dilakukan individu dalam mencapai tujuan pembelajaran. Pencapain tujuan pembelajaran itu kemudian dapat dinyatakan sebagai hasil belajar.

\section{SIMPULAN}

Pembelajaran matematika dengan model problem based learning pada kurikulum 2013 dapat meningkatkan kemampuan pemecahan masalah matematika dan keterampilan proses siswa atau aktivitas siswa dalam mengikuti pembelajaran.

\section{UCAPAN TERIMAKASIH}

Penulis ucapkan terimakasih kepada segenap Tim Pengelola Jurnal Anargya yang telah memberi kesempatan untuk mempublikasikan karya ilmiah.

\section{DAFTAR PUSTAKA}

'Ula, I.,D et.al. (2018). Efektivitas Model Pembelajaran Think-Pair-Share (TPS) Terhadap Kemampuan Komunikasi Matematis Siswa. Anargya: Jurnal Pendidikan Matematika, Vol. 1 No.1.

Ari, A., A. \& Katranc1 Y. (2014) Procedia Social and Behavioral Sciences 116. 1826-1831.

Bradshaw, Z. \& Hazell, A. (2017) "Developing problem-solving skills in mathematics: a lesson study", International Journal for Lesson and Learning Studies, Vol. 6 Issue: 1, pp.32-44.

Davidson, N., \& Major, C. H. (2014). Boundary crossings: Cooperative learning, collaborative learning, and problem-based learning. Journal on Excellence in College Teaching, 25 (3\&4), 7-55.
Häkkinen, P., Järvelä, S., Mäkitalo-Siegl, K., Ahonen, A., Näykki, P., \& Valtonen, T. (2017). Preparing teacher-students for twenty-first-century learning practices (PREP 21) : a framework for enhancing collaborative problem-solving and strategic learning skills. Teachers and Teaching: Theory and Practice, 23 (1), 25-41.

Kamaruddin SA. (2012). Character Education and Students Social Behavior. Journal of Education and Learning. Vol.6 (4) pp. 223-230.

Karatas, I \& Baki, A. (2017). The Effect of Learning Environments Based on Problem Solving on Students' Achievements of Problem Solving. International Electronic Journal of Elementary Education, 2013, 5(3), 249268.

Polya, G. 1973. How To Solve It "A New Aspect Of Mathematical Method" Second Edition. USA: Princeton Univesity Press.

Savery, J. R. (2006). Overview of Problem-based Learning: Definitions and Distinctions.Interdisciplinary Journal of Problem-Based Learning, 1(1). Available at:https://doi.org/10.7771/15415015.1002.

Servant \& Miklos (2018) The Harvard Connection: How the Case Method Spawned Problem-Based Learning at McMaster University. Health Professions Education.

Sugiyono (2015). Metode Penelitian Kombinasi (Mixed Methods). Bandung: Alfabeta. 
